\title{
Soft tissue sarcomas in agriculture and forestry workers
}

\author{
R BALARAJAN ${ }^{1}$ AND E D ACHESON²
}

From the Office of Population Censuses and Surveys, ${ }^{1}$ London WC2B, and Department of Community Medicine, ${ }^{1}$ University of Southampton, and MRC Environmental Epidemiology Unit, ${ }^{2}$ University of Southampton, Southampton General Hospital, Southampton SO9 4XY, UK

SUMmary The National Cancer Register maintained by the Office of Population Censuses and Surveys (OPCS) was used to investigate the relative risks of soft tissue sarcomas among farmers, agricultural workers, and related occupational groups. The relative risk for the group as a whole was $1 \cdot 15(95 \%$ confidence limits $0 \cdot 83-1 \cdot 59)$. One of the four subgroups (which comprises farmers, farm managers, and market gardeners) experienced a relative risk of 1.7 which just achieves significance at the $5 \%$ level (95\% confidence limits $1 \cdot 00-2 \cdot 88)$. The risks in the other three subgroups were respectively $1 \cdot 0$ (agricultural workers, 003), $0 \cdot 7$ (gardeners and groundsmen, 005), and 1.0 (foresters and woodmen, 006). No attempt has been made in this study to determine exposure to phenoxy herbicides in cases or controls. The significance of these findings is discussed.

The first suggestion of an association between phenoxy herbicides and the occurrence of soft tissue sarcomas in man was in a series of seven cases reported from Sweden in 1977.' Two subsequent case-control studies respectively from north and south Sweden showed significantly raised relative risks associated with reported exposure to phenoxyacids and to chlorophenols. ${ }^{23}$ Raised risks were found both for phenoxyacids contaminated with 2,3,7,8-tetrachlordioxin (TCDD) and those in which TCDD is not formed during production and is therefore unlikely to be a contaminant. An excess mortality from soft tissue sarcomas has also been reported in men exposed to phenocyacids, chlorophenols, and related compounds in the United States during manufacture. ${ }^{4}$ In a recent review of these and other relevant studies it was concluded that there is suggestive evidence of a biological association between exposure to phenoxyacids (or their contaminants) and soft tissue sarcomas. ${ }^{5}$ Subsequent to this review a study has been published from New Zealand where phenoxyacetic acids including 2,4,5,-T have been used in large quantities for many years. No cases of soft tissue sarcoma were discovered in the considerable workforce (estimated between 500 and 2000) professionally concerned in spraying from the air or on the ground. A slight excess of cases was found among farmers (not significant). The relative risk among people reported probably or definitely to have been exposed to phenoxyacetic acid was $1.6(90 \%$ confidence limits 0.8-3.2) (A H Smith et al, paper given at 3rd International Symposium on Chlorinated Dioxins and Related Compounds in Austria in October 1982).

The study reported here was designed to investigate the risk of soft tissue sarcomas in farmers and related workers in England and Wales relative to men in other occupations, the assumption being that farm workers will have experienced a greater exposure to phenoxy herbicides than other workers. In this study no attempt has been made to determine exposure to herbicides in cases or controls and the job title recorded at the time of registration of the cancer has been used as a surrogate for exposure.

\section{Material and methods}

The National Cancer Register maintained by the Office of Population Censuses and Surveys (OPCS) which obtains data concerning all cases of malignant disease recorded in the 15 regional registries in England and Wales was used as the source of cases of cancer in this study. Information collected by the register includes the site and histological type of the tumour and particulars of the patient (including age, place of residence, etc) at the time of registration of the tumour. Soft tissue sarcomas and other related 
Table 1 Numbers of cases and numbers of men in each occupational unit studied (002-006). Population figures are derived from the census of England and Wales (1971). (Occupational data are recorded in a 10\% sample of men under age 75)

\begin{tabular}{|c|c|c|c|c|c|}
\hline \multirow[b]{2}{*}{ Unit code } & \multirow{2}{*}{$\frac{\text { Occupation }}{\text { Title }}$} & \multicolumn{4}{|l|}{ Age } \\
\hline & & $15-44$ & $45-64$ & $65-74$ & $\geqslant 75$ \\
\hline 002 & $\begin{array}{l}\text { Farmers, farm managers, } \\
\text { market gardeners }\end{array}$ & $\begin{array}{lr}\text { Cases } & 5 \\
\text { Population } & 95140\end{array}$ & $\begin{array}{r}22 \\
98640\end{array}$ & $\begin{array}{r}6 \\
43690\end{array}$ & 9 \\
\hline 003 & $\begin{array}{l}\text { Agricultural workers } \\
\text { nec }\end{array}$ & $\begin{array}{lr}\text { Cases } & 3 \\
\text { Population } & 114830\end{array}$ & $\begin{array}{r}11 \\
60280\end{array}$ & $\begin{array}{r}7 \\
28460\end{array}$ & 2 \\
\hline 004 & $\begin{array}{l}\text { Agricultural machinery } \\
\text { drivers }\end{array}$ & $\begin{array}{lr}\text { Cases } & - \\
\text { Population } & 12520\end{array}$ & $57 \overline{-}$ & 1270 & $\bar{*}$ \\
\hline 005 & Gardeners and groundsmen & $\begin{array}{lr}\text { Cases } & 4 \\
\text { Population } & 43430\end{array}$ & 53870 & $\begin{array}{r}7 \\
34160\end{array}$ & 1 \\
\hline 006 & Foresters and woodmen & $\begin{array}{lr}\text { Cases } & 1 \\
\text { Population } & 8070\end{array}$ & 5590 & $\begin{array}{r}1 \\
1960\end{array}$ & $\overline{-}$ \\
\hline $002-006$ & $\begin{array}{l}\text { Workers in agriculture } \\
\text { and forestry }\end{array}$ & $\begin{array}{lr}\text { Cases } & 13 \\
\text { Population } 273990\end{array}$ & $\begin{array}{r}38 \\
224160\end{array}$ & 109540 & 12 \\
\hline
\end{tabular}

*No population data available.

nec $=$ Not elsewhere classified.

neoplasms are coded according to the 8th International Classification of Diseases under the ICD category $171 .^{\circ}$

Information about the occupation of the patient at the time of registration is also collected and coded ${ }^{8}$ and in men is available in a form suitable for analysis in about $70 \%$ of cases of malignant neoplasm of connective tissue and $60 \%$ of cases of other neoplasms. The specific occupational units as defined in the Classification of Occupations ${ }^{7}$ were as follows: farmers, farm managers, and market gardeners (002); agricultural workers (003); agricultural machinery drivers (004); gardeners and groundsmen (005); foresters and farmers (006).

The cases in the study were 1961 men (15 years and over) registered with the diagnosis of malignant neoplasm of connective tissue and other soft tissue (ICD 171) in the years 1968-76 in England and Wales in whom information about occupation was available. Unlike the Swedish investigators mentioned above we did not include malignant tumours of connective tissues of the hollow viscerafor instance, leiomysarcomas and sarcomas of the stomach-as these are classified elsewhere than in ICD 171 with carcinomas of the appropriate organ. The controls (also obtained from the National Cancer Register within each year of registration) were men registered with any cancer other than that belonging to ICD 171 with a valid occupational code randomly matched 1:1 for age (within five years) and region of residence.

Relative risks were calculated for each of the defined occupations and for the group as a whole by matched pair analyses. McNemar's test was applied to test for a significant excess in the cases over that of the controls. ${ }^{8}$ Confidence intervals were calculated using the method described by Breslow and Day. ${ }^{9}$ The histology of the tumours as recorded in the registry were also studied for each of the different units.

\section{Results}

Table 1 shows numbers of cases by age, together with the appropriate denominator from the 1971 census of England and Wales. A total of 1961 matched pairs of cases and controls was available for analysis over the period 1968-76. The relative risk of soft tissue sarcomas among farmers and allied workers (occupational units 002-006) was $1 \cdot 15(95 \%$ confidence limits 0.83-1.59) (table 2). Table 3 shows that when individual years were examined a raised relative risk was present in each year except 1968 and 1973.

Table 4 shows that when each occupational unit was analysed separately the excess risk found was limited to farmers, farm managers, and market gardeners (occupation unit 002). In this unit the relative risk was 1.7 (95\% confidence limits 1.00

Table 2 Employment among agricultural and forestry workers (002-006) compared with other occupations within matched case-control pairs (1968-76)

\begin{tabular}{lll}
\hline & \multicolumn{2}{l}{ Cases } \\
\cline { 2 - 3 } Controls & $\begin{array}{l}\text { Workers in agriculture } \\
\text { and forestry* }\end{array}$ & $\begin{array}{l}\text { Other } \\
\text { occupations }\end{array}$ \\
\hline $\begin{array}{l}\text { Workers in agriculture } \\
\text { and forestry* }\end{array}$ & 9 & 73 \\
Other occupations & 84 & 1795 \\
\hline
\end{tabular}

$\mathbf{N}=1961$.

Relative risk $1 \cdot 15$ (95\% confidence interval $0 \cdot 83-1 \cdot 59)$.

* As defined in text. 
Table 3 Relative risks among workers in agriculture and forestry (002-006) by individual years

\begin{tabular}{llll}
\hline Year & $\begin{array}{l}\text { No of } \\
\text { matched pairs }\end{array}$ & $\begin{array}{l}\text { Relative } \\
\text { risk }\end{array}$ & $\begin{array}{l}\text { 95\% Confidence } \\
\text { interval }\end{array}$ \\
\hline 1968 & 171 & $0 \cdot 7$ & $0 \cdot 23-2 \cdot 04$ \\
1969 & 170 & $1 \cdot 0$ & $0 \cdot 23-4 \cdot 35$ \\
1970 & 185 & $1 \cdot 5$ & $0 \cdot 63-3 \cdot 73$ \\
1971 & 230 & $1 \cdot 2$ & $0 \cdot 34-4 \cdot 20$ \\
1972 & 195 & $1 \cdot 3$ & $0 \cdot 43-4 \cdot 06$ \\
1973 & 257 & $0 \cdot 8$ & $0 \cdot 27-2 \cdot 25$ \\
1974 & 246 & $1 \cdot 2$ & $0 \cdot 48-3 \cdot 10$ \\
1975 & 246 & $1 \cdot 1$ & $0 \cdot 42-2 \cdot 89$ \\
1976 & 261 & $2 \cdot 0$ & $0 \cdot 62-7 \cdot 46$ \\
\hline
\end{tabular}

$2 \cdot 88)$. When the nine year period of the study was divided into three equal periods the relative risk for unit 002 were respectively as follows: $1968-701 \cdot 7$; 1971-3 1.0; and 1974-6 2.5. No cases were found among the agricultural machinery drivers (004). The age distribution of cases among the high risk occupation units (002-006) did not differ significantly from the distribution of all other occupations combined.

The histological classification of the tumours as recorded in the National Cancer Registry is shown by

Table 4 Relative risk among individual occupation units (1968-76)

\begin{tabular}{llll}
\hline Occupation units & & $\begin{array}{l}\text { No of cases } \\
\text { observed }\end{array}$ & $\begin{array}{l}\text { Relative } \\
\text { risk }\end{array}$ \\
\hline $\begin{array}{l}\text { Farmers, farm managers } \\
\text { and market gardeners }\end{array}$ & $(002)$ & 42 & 1.7 \\
interval
\end{tabular}

Table 5 Histology of soft tissue sarcoma among occupations (1971-6)

\begin{tabular}{|c|c|c|c|c|c|c|c|c|c|c|c|c|}
\hline & \multicolumn{2}{|c|}{$\begin{array}{l}\text { Farmers, } \\
\text { farm managers, } \\
\text { and market } \\
\text { gardeners } \\
(002)\end{array}$} & \multicolumn{2}{|c|}{$\begin{array}{l}\text { Agricultural } \\
\text { workers } \\
\text { (003) }\end{array}$} & \multicolumn{2}{|c|}{$\begin{array}{l}\text { Gardeners } \\
\text { and } \\
\text { groundsmen } \\
\text { (005) }\end{array}$} & \multicolumn{2}{|c|}{$\begin{array}{l}\text { Foresters } \\
\text { and woodmen } \\
(006)\end{array}$} & \multicolumn{2}{|c|}{$\begin{array}{l}\text { Agriculture } \\
\text { and } \\
\text { forestry workers } \\
(002-6)\end{array}$} & \multicolumn{2}{|c|}{$\begin{array}{l}\text { Other } \\
\text { occupations } \\
\text { (001, } \\
007-223)\end{array}$} \\
\hline & No & $\%$ & No & $\%$ & No & $\%$ & No & $\%$ & No & $\%$ & No & $\%$ \\
\hline $\begin{array}{l}\text { Fibromatous neoplasms: } \\
\text { Fibrosarcoma } \\
\text { Other sarcomas }\end{array}$ & $\begin{array}{l}9 \\
-\end{array}$ & ( 29.0) & $\begin{array}{l}6 \\
-\end{array}$ & $(28 \cdot 5)$ & $\begin{array}{l}1 \\
-\end{array}$ & $(12 \cdot 5)$ & $\begin{array}{l}1 \\
-\end{array}$ & $(50 \cdot 0)$ & $\begin{array}{r}17 \\
-\end{array}$ & $(27 \cdot 4)$ & $\begin{array}{r}515 \\
24\end{array}$ & $\begin{array}{r}(39.0) \\
(1.8)\end{array}$ \\
\hline $\begin{array}{l}\text { Myxomatous neoplasms: } \\
\text { Myxosarcoma }\end{array}$ & - & & 1 & $(4 \cdot 8)$ & - & & - & & 1 & (1.6) & 21 & (1.6) \\
\hline $\begin{array}{l}\text { Lipomatous neoplasms: } \\
\text { Liposarcoma } \\
\text { Other sarcomas }\end{array}$ & $\begin{array}{l}8 \\
-\end{array}$ & $(25 \cdot 8)$ & $\begin{array}{l}1 \\
-\end{array}$ & $(4 \cdot 8)$ & $\begin{array}{l}1 \\
-\end{array}$ & $(12 \cdot 5)$ & $\begin{array}{l}1 \\
-\end{array}$ & $(50 \cdot 0)$ & $\begin{array}{r}11 \\
-\end{array}$ & $(\mathbf{1 7 \cdot 7 )}$ & $\begin{array}{r}208 \\
1\end{array}$ & $\begin{array}{r}(15 \cdot 8) \\
(0 \cdot 1)\end{array}$ \\
\hline $\begin{array}{l}\text { Myomatous neoplasms: } \\
\text { Leiomyosarcoma } \\
\text { Rhabdomyosarcoma }\end{array}$ & $\begin{array}{l}1 \\
-\end{array}$ & (3.2 & $\begin{array}{l}3 \\
2\end{array}$ & $\begin{array}{r}(14 \cdot 3) \\
(9 \cdot 5)\end{array}$ & $\begin{array}{l}1 \\
1\end{array}$ & $\begin{array}{l}(12 \cdot 5) \\
(12 \cdot 5)\end{array}$ & $\begin{array}{l}- \\
-\end{array}$ & & $\begin{array}{l}5 \\
3\end{array}$ & $\begin{array}{r}(8 \cdot 0) \\
(4 \cdot 8)\end{array}$ & $\begin{array}{r}106 \\
93\end{array}$ & $\begin{array}{l}(8 \cdot 0) \\
(7 \cdot 1)\end{array}$ \\
\hline $\begin{array}{l}\text { Synovial neoplasms: } \\
\text { Synovial sarcoma }\end{array}$ & 3 & $(9 \cdot 7)$ & - & & - & & - & & 3 & $(4 \cdot 8)$ & 43 & (3.3) \\
\hline $\begin{array}{l}\text { Blood vessel neoplasms: } \\
\text { Haemangiosarcoma } \\
\text { Peritheliosarcoma } \\
\text { Other sarcomas }\end{array}$ & $\begin{array}{l}2 \\
- \\
-\end{array}$ & $(6 \cdot 5)$ & $\begin{array}{l}3 \\
- \\
-\end{array}$ & $(14 \cdot 2)$ & $\overline{1}$ & $(12 \cdot 5)$ & $\begin{array}{l}- \\
-\end{array}$ & & $\begin{array}{l}5 \\
1 \\
-\end{array}$ & $\begin{array}{r}(8 \cdot 0) \\
(1 \cdot 6)\end{array}$ & $\begin{array}{l}31 \\
26 \\
14\end{array}$ & $\begin{array}{l}(2 \cdot 4) \\
(2 \cdot 0) \\
(1 \cdot 1)\end{array}$ \\
\hline $\begin{array}{l}\text { Nerve sheath neoplasms: } \\
\text { Neurofibrosarcoma }\end{array}$ & - & & - & & - & & - & & - & & 5 & $(0 \cdot 4)$ \\
\hline Alveolar soft part sarcoma & - & & - & & - & & - & & - & & 10 & $(0 \cdot 8)$ \\
\hline $\begin{array}{l}\text { Other sarcomas and } \\
\text { sarcomas NOS }\end{array}$ & 8 & $(25 \cdot 8)$ & 5 & $(23 \cdot 8)$ & 3 & $(37 \cdot 5)$ & - & & 16 & $(25 \cdot 8)$ & 221 & $(16 \cdot 8)$ \\
\hline & 31 & $(100 \cdot 0)$ & 21 & $(100 \cdot 0)$ & 8 & $(100 \cdot 0)$ & 2 & $(100 \cdot 0)$ & 62 & $(100 \cdot 0)$ & 1318 & $(100 \cdot 0)$ \\
\hline
\end{tabular}

NOS $=$ Not otherwise specified. 
occupational unit in table 5 . No convincing differences are present between the distributions.

\section{Discussion}

The positive finding in this study-namely, the statistically significant association between the occurrence of soft tissues tumours and occupational unit 002 (farmers, farm managers, and market gardeners) - may be due to a carcinogen to which farmers are exposed more commonly than other men, bias, an unknown factor, or chance. While the first possibility must be given serious consideration it is difficult to envisage a carcinogen to which farmers, farm managers, and market gardeners are exposed and agricultural labourers, gardeners and groundsmen, and foresters are not.

Both mortality and morbidity statistics show that agricultural workers have a lower than average incidence of cancer, largely because of low rates of lung cancer. For this reason the use of all other cancers as controls will tend to exaggerate any association between farming and soft tissue tumours. Nevertheless, it might be expected that this bias would affect each of the four occupational units under consideration and not be limited to unit 002 . The absence of a significantly increased relative risk in workers in agricultural and forestry as a whole and its presence in one of four subgroups may indicate that this is a chance finding. Table 1 shows that within unit 002 nine of the 42 were over 75 at the time the tumours were diagnosed during the period 1968-76. As men of this age are probably less likely to have been exposed to phenoxy herbicides the relative risk to farmers, farm managers, and market gardeners was recalculated excluding cases and controls over age 75 . It was $\mathbf{1 . 4 3}$ (95\% confidence limits 0.82 $2 \cdot 56)$.

The occupations used in the analysis were those recorded at the time of registration of the cancer. Several who had previously been employed as farm workers will therefore have been classified to other more recent occupations and vice versa. These misclassifications will have the effect of reducing the strength of any association.
We wish to thank Alan Scott (cancer registration), Nick Cartwright (computing division), and Pat Dixon (medical statistics) of the Office of Population Censuses and Surveys and David Machin, community medicine, Southampton Medical School, for statistical advice.

Requests for reprints to: Dr R Balarajan, Medical Statistics, Office of Population Censuses and Surveys, 10 Kingsway, London WC2B.

\section{References}

${ }^{1} \mathrm{Hardell} \mathrm{L}$. Soft tissue sarcomas and exposure to phenoxy acids-a clinical observation. Larkartidningen 1977; 74: 2753-4. (In Swedish.)

${ }^{2}$ Hardell L, Sandstrom A. Case control study: soft tissue sarcomas and exposure to phenoxyacetic acids or chlorophenols. Br J Cancer 1979; 39: 711-7.

${ }^{3}$ Eriksson M, Hardell L, Berg NO, Moller T, Axelson O. Soft tissue sarcomas and exposure to chemical substances; a case referent study. BrJ Ind Med 1981; 38: 27-33.

${ }^{4}$ Honcher PA, Halperin WE. 2,4,5,-T, trichlorphenol and soft tissue sarcomas. Lancet 1981; i: 268-9.

${ }^{5}$ Coggon D, Acheson ED. Do phenoxy herbicides cause cancer in man? Lancet 1982; i: 1957-9.

${ }^{6}$ World Health Organisation. International classification of diseases. 8th rev. Geneva: WHO, 1975.

'Office of Population Censuses and Surveys. Classification of occupations. London: HMSO, 1970.

${ }^{8}$ MacMahon B, Pugh T. Epidemiology principles and methods. Boston: Little, Brown and Co, 1970.

${ }^{9}$ Breslow NE, Day NE. Statistical methods in cancer research. Lyon: International Agency for Research on Cancer, 1980: 164-6. 